\title{
The socio-economic impacts of the silver-cheeked toadfish on small-scale fishers: A comparative study from the Turkish coast
}

\section{Benekli balon balığının küçük ölçekli balıkçılar üzerindeki sosyo-ekonomik etkisi:: Türk kıyılarından karşılaştırmalı bir çalışma}

\section{Vahdet Ünal • Huriye Göncüoğlu Bodur* (D)}

Ege University, Faculty of Fisheries, Bornova, Izmir, Turkey

*Corresponding author: huriyegoncuoglu@gmail.com

\section{How to cite this paper:}

Ünal, V. \& Göncüoğlu Bodur, H. (2017). The socio-economic impacts of the silver-cheeked toadfish on small-scale fishers: A comparative study from the Turkish coast. Ege Journal of Fisheries and Aquatic Sciences, 34(2): 119-127. doi:10.12714/egejfas.2017.34.2.01

\begin{abstract}
The silver-cheeked toadfish, Lagocephalus sceleratus (Gmelin, 1789), which is enlisted as one of the problematic 100 invasive species in the Mediterranean, entered the Turkish waters in 2003 and since then it has negatively affected the ecosystem and became a major concern for the small-scale fishers. The aim of the present study is to assess the socio-economic impacts of silver-cheeked toadfish on small-scale fishers operating along the Turkish-Mediterranean and the Aegean coast. The research is based on a dataset collected between January 1st, 2013 and January 1st, 2014 using face-to-face interviews with 215 fishers from 7 coastal cities from Izmir-Çesme in the Middle Aegean region to Hatay-Samandağ in the Syrian border.The data obtained in the present study were compared to the data of the only existing previous study carried out by the same researchers in the same coastal cities between 2011-2012 in order to understand the proportion and the direction of the change after two years. The results of this study support other literature, which indicates that silver-cheeked toadfish damage small-scale fisheries. Almost all of the fishers (97\%) stated that this species damages their fishing gears and the fish entangled to these fishing gears. The loss caused by silver-cheeked toadfish in 2013-2014 increased by more than double compared to the 2011-2012 period, and in this regard, we hope that such results increase awareness amongst decision-makers. Consequently, there is a definite need for policies and measures (e.g. bounty system, permission of fishing in certain time of the year) to reduce or eliminate the negative effects of the silver-cheeked toadfish on fishers. Imminent decisions to support fishers should be taken based on best available scientific data. We think that further studies should be implemented to monitor the association and interaction between silver-toad fish, other species, the ecosystem, and the socio-economic impact of the pufferfish.
\end{abstract}

Keywords: Pufferfish, silver-cheeked toadfish, Lagocephalus sceleratus, monetary loss, socio-economic impacts, small-scale fisheries, invasive species

Öz: Akdeniz'in sorunlu 100 işgalci türü arasında gösterilen Benekli balon balı̆ı (Lagocephalus sceleratus) (Gmelin, 1789), Türkiye denizlerinde ilk defa 2013 yilında görülmüş ve o tarihten bugüne kadar ekosistemi olumsuz yönde etkileyerek tüm küçük ölçekli balıkçılar için büyük bir sorun haline gelmiştir. Bu çalışmanın amacı, Akdeniz ve Ege'nin Türkiye kıyılarındaki küçük ölçekli balıkçılar tarafından karşılaşılan benekli balon balığının sosyo-ekonomik etkilerini belirlemektir. Araşıırma, 1 Ocak 2013 - 1 Ocak 2014 tarihleri arasında, Orta Ege'de İmir-Çeşme'den Suriye sıııında Hatay-Samandağ arasında kalan 7 adet kıyı kentinde 215 balıkçı ile yapılan yüz yüze görüşmelerden toplanan verilere dayanmaktadır. Çalışmada elde edilen veriler, daha önce de aynı araştırmacılar tarafından 2011-2012 yılları arasında aynı bölgelerde gerçekeştirilmiş olan tek çalışma ile karşısaştıılarak iki yıl içinde meydana gelen değişiklikler ve oranları anlaşılmaya çalışımıștı. Çalışmanın sonuçları, benekli balon baliğının küçük ölçekli balıkçı̆lğa zarar verdiğini ortaya koyan diğer araştırmalarla örtüşmektedir. Görüşülen balıkçıarın tamamına yakını (\%97) bu türün av araçlarına ve ağlara takılan balıklara zarar verdiğini belirtmiștir. 2013-2014 arasında benekli balon balığının sebep olduğu kayıpların, 2011-2012 dönemindekine oranla iki kattan daha fazla oranda artmış olduğu tespit edilmiştir. Çalışmada ortaya konan sonuçlar sayesinde karar vericiler arasında farkındalığın artması umulmaktadır. Buna bağlı olarak, benekli balon balığının olumsuz etkilerinin azaltııması ya da ortadan kaldırıması yönünde politikaların geliş̧irilmesi ve önlemlerin alınması yönünde bir ihtiyaç olduğu açıkça belirlenmiş̧tir. Eldeki en doğru bilimsel veriler ışığında, balıkçırıı destekleyecek acil kararların alınması (örn. prim sistemi, ylın belirli zamanlarında avlanmasına izin verilmesi) gerekmektedir. Benekli balon balığı, diğer türler, ekosistem ve bu türün sosyo-ekonomik etkileri arasındaki ilişki ve etkileșimin izlenmesi konusunda daha fazla çalışma yapılmasının gerekli olduğu düşünülmektedir.

Anahtar kelimeler: Balon balığı, benekli balon balığı, Lagocephalus sceleratus, maddi kayıp, sosyo-ekonomik etkiler, küçük ölçekli balıkçılık, işgalci türler

\section{INTRODUCTION}

Monitoring studies in fisheries generally focus on ecological and biological dynamics of fish stocks (Baxter et al., 2001). The idea that ecological and biological monitoring of the marine ecosystem on a regular and systematic basis is sufficient (Genovesi and Shine, 2004; Nehring et al., 2009; Otero et al.,
2013) has recently changed (Bunce et al., 2000; Pomeroy et al., 2004; Otero et al., 2013; Richmond et al., 2015; IUCN, 2015). The consideration of social and economic aspects of fisheries has been increasing amogst both managers and policy-makers in the recent decades (Freudenburg, 1986; 
Vanderpool, 1987; Dyer and Poggie, 2000; Cai et al., 2005; Hall, et al., 2009; Pollnac et al., 2006; Tuler et al., 2013; Richmond et al., 2015).

Similarly, the importance of revealing the socio-economic impacts on the subjects of fishery management, artificial reef studies, marine protected areas, and climate change is discussed in detail in many studies (Cochrane et al. 2009; Wongbusarakum and Loper, 2011; Fischer et al. 2015). Furthermore, rebuilding ecosytems and ecosystem-based fisheries are paid more attention by academics, decision makers, and NGOs. The study of socio-economic impacts deriving from non-native species has also been considered as of prime importance (Pomeroy et al., 2004) especially in the case of invasive species for they sometimes create irreversible ecological and socio-economic damage (Galil, 2008; UNEPMAP-RAC/SPA, 2005; Zenetos et al., 2010; Katsanevakis et al., 2015). Marine invasions have both socio-economic and human health implications. In Europe, the economic impacts of non-native terrestrial and aquatic species have been estimated to be at least EUR 12.5 billion per year, and probably over EUR 20 billion (Shine et al., 2008). Of that, the negative impact of aquatic invasive species alone has been estimated to cost the region at least EUR 2.2 billion per year (Otero et al., 2013).

The Mediterranean Sea has been an interesting place since the Suez Canal was opened in 1869; the entrance of non-native species from the Red Sea to the Mediterranean Sea has been on the rise as recent studies show that a total of $925^{1}$ non-native species have been recorded in the Mediterranean to date. These hail from 13 phyla and include molluscs (216 species), fishes (127 species), plants (124 species), and crustaceans (106 species) (UNEP-MAP-RAC/SPA, 2011).

The focus of this study falls on one specific species, namely the silver-cheeked toadfish (Lagocephalus sceleratus), which was recorded for the first time along the Mediterranean-Turkish coasts in 2003 (Akyol et al., 2005).

Some studies have shown that this species causes socioeconomic damages on different forms of fisheries (Nader et al., 2012; Otero et al., 2013), and the results of an FAO project focusing on the eastern Mediterranean show that the silvercheeked toadfish has caused economic damage on passive fishing gears and longline fisheries (EASTMED, 2010). In Turkey where the landing of this species is prohibited due to its poison, it has been reported that a total of 4,719 fishers have suffered a loss of approximately EUR 2 million per year because of the silver-cheeked toadfish (Ünal et al., 2015). Despite such findings, monitoring is still lacking, and no compensatory policies have been implemented to cater for the damage suffered by fishers. In this regard, the present study seeks to reveal the socio-economic impact of the silvercheeked toadfish on small-scale fishers along the Turkish Mediterranean and Aegean coasts and provide tangible recommendations to reduce the derailing effects caused by the silver-cheeked toadfish.

\section{MATERIALS AND METHODS}

The study area consists of 5,187 fishing vessels performing small-scale fishing $(<12 \mathrm{~m})$ (SUBIS, 2013), 30 fishing ports (Fishing Port Regulation, Rev; 2008), and 45 fishing cooperatives (Ünal, et.al., 2014). Between 2013 and 2014, a representative sample of face-to-face interviews with smallscale fishers were conducted in 32 towns and villages in the provinces of Antalya, Mersin, Adana, Hatay, Muğla, Aydın, and Izmir (Figure 1).

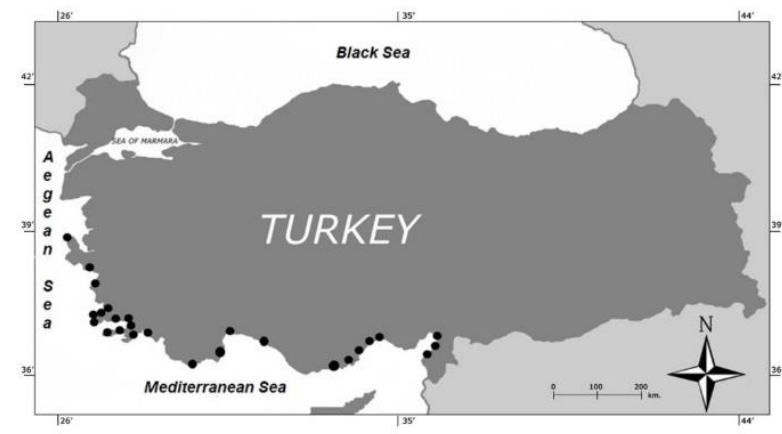

Figure 1. The study area

Interviews at the Mediterranean and Agean fishing ports were specfically carried out with small-scale fishers who were affected by any form of damage by the silver-cheeked toadfish.

The data was collected from fishers based on their personal declaration. It was spent time with fishers at the field, sailed for fishing, and observed impacts of silver-cheeked toadfish on their fishing gears. In addition to abovementioned efforts, faceto-face survey was conducted in order to reach the most possible reliable data.

Based on a previous study conducted by Ünal et al (2015), the questions used in this research has inquired about the following criteria (Table 1).

Table 1. Sections of the questinnaire used in the present study

1. Socio-demographics of fishers
2. Characteristics of fishing (in general)
3. Characteristics of the silver-cheeked toadfish fishing (bycatch)
4. The silver-cheeked toadfish problem and damages caused by
this species
5. Solutions for the silver-cheeked toadfish problem

Consider estimation of the proportion $\mathrm{C}$ of individuals in a population size of $\mathrm{N}$ who possess a certain attribute. If necessary, variance $Q_{, 5}^{C}$ of the sample proportion is specified, the required sample size to estimate was calculated based on

\footnotetext{
${ }^{1}$ It is not known exactly that how many of them has been monitored periodically.
} 
the formula (modified from Miran, 2003 and Newbold et. al., 2013):

$$
n=\frac{N C(1-C)}{(N-1) \sigma_{C}^{2}+C(1-C)}
$$

where $\mathrm{n}$ is the sample size, $\mathrm{N}$ is the total population of the target group, $C$ is the contribution ratio ( 0.50 is fitted to reach maximum sample size), and $\sigma_{C}^{2}$ is the variance. The largest possible value of this expression, whatever the value of $C$, is

$$
n_{\max }=\frac{0.25 N}{(N-1) \sigma_{C}^{2}+0.25}
$$

A 99\% confidence interval for the population proportion will extend approximately $1.645 \sigma_{c}=0.05\left(\sigma_{c}=0.0304\right)$ on each side of the sample proportion. So, the number of vessels sampled in the survey was found to be 215 , with $5.5 \%$ error margin and $99 \%$ confidence interval. It was reached to 303 fishers, however 88 of them rejected to be interviewed.

\section{Calculation of economic impacts}

The calculation of economic loss caused by the silvercheeked toadfish is a difficult task and might raise scientific queries. Since no objective criteria are available at the moment, the quantitative results given in this study might be controversial (Ünal et al., 2015); however, given the urge of the issue, preliminary results are necessary to address the consequences. Personal declarations from fishermen were collected at the field and during onboard observations, the impacts of the silver-cheeked toadfish were recorded first hand.

The calculation of the total monetary loss originating from the fishers'fishing gears of was found by multiplying the monetary equivalent of the pufferfish-induced damage in the fishers' fishing gears with the total number of fishers interviewed.

Labour losses of fishers engaging in longline fishing were also determined in this study. If the monthly average wages of the permanent agricultural workers in 2013 are taken as a basis by the Turkish Statistical Institute (TUKSTAT, 2014), the monthly average wage of the agricultural worker in 2013 equals to $1,262 \mathrm{TL}(5.2 \mathrm{TL} / \mathrm{hr})$. Accordingly, the minimum wage and time spent on the longline equipment were taken as a basis for the measurement of the average labor loss of a fisher. The pufferfish-originated labor costs of the fishers performing fishing with gillnets were included in the general net repair and maintenance costs.

\section{Developing solutions for silver-cheeked toadfish problem}

The fishers' opinions on potential solutions for the damage caused by the silver-cheeked toadfish were recorded in terms of the following criteria: (a) implementation of the bounty system, (b) determination of the most appropriate fishing gear for pufferfish fishing, (c) raising awareness, and determination of the expectations from official institutions.

\section{RESULTS}

\section{Socio-demographics}

The average age of the fishers interviewed is $45 \pm 12$ years. The youngest fisher is 23 , the oldest one is 84 years old. The education level of the fishers was found to be $7 \pm 3$ years, and their fishing experience was found to be $24 \pm 13$ years. The household population is $4 \pm 1$ people, and the fishers stated that they are obliged to sustain and nurture $3 \pm 1$ people with the money they earn. $83 \%$ of the fishers stated that they are married and $70 \%$ of them have social security. More than half of the respondents $(59 \%)$ expressed that they have no other source of income except fishing and $85 \%$ reported that their monthly income is between 501 and 1500 TL showing that generally fishers have a low income. As a result of the analysis of the annual total fishing income, the highest frequency (54\%) was detected to be between 501-1000 TL and the income range following it with $31 \%$ was $1001-1500 \mathrm{TL}$. The sociodemographic characteristics of the fishers are presented in Table 2.

Table 2. Socio-demographic characteristics of fishers (2013-2014)

\begin{tabular}{lll}
\hline Category & Variable & $\%$ \\
\hline \multirow{3}{*}{ Age (years) } & $20-29$ & 11 \\
& $30-39$ & 27 \\
& $40-49$ & 25 \\
& $50-59$ & 26 \\
& $>60$ & 12 \\
\hline \multirow{2}{*}{ Marital status } & Single & 20 \\
& Married & 80 \\
\hline \multirow{4}{*}{ Level of education } & Illiterate & 1 \\
& Literate & 6 \\
& 5 years of education & 45 \\
& 8 years of education & 18 \\
& 11 years of education & 23 \\
& $>11$ years of education & 7 \\
\hline \multirow{2}{*}{ Social security } & With social security & 70 \\
& Without social security & 30 \\
\hline \multirow{2}{*}{ Second Income } & Fishing only & 59 \\
\hline \multirow{2}{*}{ Fishing experience (years) } & Having a second income & 41 \\
\cline { 2 - 3 } & $11-10$ & 15 \\
\end{tabular}




\begin{tabular}{llc}
$21-30$ & 20 \\
& $31-40$ & 16 \\
& $>41$ & 9 \\
\hline$<500$ & 4 \\
& $501-1000$ & 54 \\
Monthly income range per & $1001-1500$ & 31 \\
fishermen, TL (\%) & $1501-2000$ & 8 \\
& $2001-2500$ & 0.5 \\
& $2501-3000$ & 1 \\
\hline
\end{tabular}

ॠ1TL 0.37 Euro-2013-2014

\section{Characteristics of fishing, silver-cheeked toadfish problem, and socio-economic impacts}

Fishing with gears such as gillnets and longlines is generally preferred on the traditional wooden vessels and the activity mainly takes place within a few miles from the coast. The usually targeted species include sparids and groupers since these have good market prices. Nonetheless, due to the low catches and relatively high operational costs, fishing is not always profitable.

Small-scale fishers generally fish within the few miles from the coast. $62 \%$ of the fishers interviewed have $150-209$ working days at the sea. Annual mean days at the sea and standard deviation is $188 \pm 57$ (Table 3 ).

Table 3. Characteristics of fishing operation variables per vessel

\begin{tabular}{|c|c|c|c|}
\hline $\begin{array}{l}\text { Variables } \\
\text { Fisherman (\%) }\end{array}$ & Range or item & $\begin{array}{l}\text { Ünal et al., } 2015 \\
2011-2012 \\
\text { Value }\end{array}$ & $\begin{array}{l}\text { Present study } \\
\text { 2013-2014 } \\
\text { Value }\end{array}$ \\
\hline \multirow{5}{*}{$\begin{array}{l}\text { Annual fishing days at the sea } \\
(\%)\end{array}$} & $30-89$ & 6 & 2 \\
\hline & $90-149$ & 15 & 12 \\
\hline & $150-209$ & 37 & 62 \\
\hline & $210-269$ & 23 & 15 \\
\hline & $>270$ & 20 & 9 \\
\hline \multirow{4}{*}{ Fishing gear $(\%)$} & Longline & 31 & 38 \\
\hline & $\begin{array}{l}\text { Longline and gillnets } \\
\text { (alternately) }\end{array}$ & 38 & 27 \\
\hline & Gillnets & 29 & 35 \\
\hline & $\begin{array}{l}\text { Longline, gillnets and angling } \\
\text { (alternately) }\end{array}$ & 2 & - \\
\hline \multirow{4}{*}{$\begin{array}{l}\text { Mean daily operational costs } \\
\text { (TRY per day) }\end{array}$} & Longline & 106 TL day-1 & 141 TL day-1 \\
\hline & Longline and gillnets (alternately) & 75 TL day-1 & 151 day-1 \\
\hline & Gillnets & 81 TL day-1 & 188 day-1 \\
\hline & $\begin{array}{l}\text { Longline, gillnets and angling } \\
\text { (alternately) }\end{array}$ & 25 TL day- 1 & - \\
\hline \multirow{4}{*}{$\begin{array}{l}\text { Mean daily gross income } \\
\text { (TRY per day) }\end{array}$} & Longline & 197 TL day-1 & 176 TL day-1 \\
\hline & Longline and gillnets (alternately) & 132 TL day-1 & 189 TL day-1 \\
\hline & Gillnets & 169 TL day-1 & 198 TL day-1 \\
\hline & $\begin{array}{l}\text { Longline, gillnets and angling } \\
\text { (alternately) }\end{array}$ & 83 TL day-1 & - \\
\hline
\end{tabular}

TL, The Turkish Lira (1TL 0.34 Euro-2011-2012; 1TL 0.37 Euro-2013-2014)

The silver-cheeked toadfish, an undesirable species for fishers, is observed in each period of the year, and the fishers stated that March is the month with the highest prevalence of pufferfish, and January is the month with the lowest prevalence.
It does not only damage the fishing gears of fishers, at the same time it also attacks the fish entangled in the fishing gear. Therefore, it causes financial losses for the fishers by reducing fishing yield and value. $97 \%$ of the fishers stated that the fish 
entangled in nets (gillnets and longline) is damaged by silvercheeked toadfish. The fishers stated that they observed a decrease in their products fished by them in fishing areas since the time the silver-cheeked toadfish started to create problems. The fishers defined the damage on the fish in fishing gears caused by the silver-cheeked toadfish such as:

a. "Due to the structure of its mouth and teeth, it cuts the place it has bitten at one time and takes it"

b. "I recognize pufferfish from its way of eating fish in the fishing gear; when pufferfish comes, only the fish's head remains in the longline I use"

c. "I recognize pufferfish from the form of biting-cutting (in the form of crescent)"

d. "It comes to the surface when we pull the net up or pull the longline, and we see it then" e. "It breaks off the hook"

f. "It gets in the net and tears the net into pieces; every day, around $3 \mathrm{~kg}$ of fish become torn to pieces and unsaleable"

g. "Fish comes eaten in our fishing gear. We see that tail and internal organs, soft parts of the fish are eaten"

h. "It bites off the part of the fish in the net and goes away"

i. "It cuts the net or fishing line like a knife"

The losses of the fishers according to the fishing gears they prefer are presented in Table 4. The average silver-cheeked toadfish originated loss in 2013-2014 in longline is 2,336 TL/vessel, and in gillnets is 2,821 TL/vessel (Table 4)

Table 4. Comparative monetary losses by fishing vessel related to gear damage caused by the silver-cheeked toadfish

\begin{tabular}{|c|c|c|c|}
\hline \multirow[t]{2}{*}{ Gear type } & \multicolumn{3}{|l|}{$\begin{array}{l}\text { Annual monetary loss (TRY) } \\
\text { Mean } \pm \text { SD }\end{array}$} \\
\hline & $\begin{array}{c}\text { Ünal et al., } 2015 \\
2011-2012 \\
\text { Value }\end{array}$ & $\begin{array}{c}\text { Present study } \\
\text { 2013-2014 } \\
\text { Value }\end{array}$ & $\begin{array}{l}\text { Proportion of the change } \\
\qquad(\%)\end{array}$ \\
\hline Longline & $942.4 \pm 1,007.7$ & $2,336.1 \pm 2,087.9$ & 148 \\
\hline Gillnet & $1,346.9 \pm 1,451.0$ & $2,820.6 \pm 3,393.4$ & 109 \\
\hline Longline and gillnet (alternately) & $1,440.6 \pm 900,7$ & $2,559.6 \pm 2,781$ & 78 \\
\hline
\end{tabular}

TL, The Turkish lira (1TL 0. 34 EUR, 2011-2012; 1TL 0.37 EUR 2013-2014), SD = standard deviation

The fishing gear loss per vessel in 2013-2014 is 2,554 TL/year and labor loss for longline is $64.7 \mathrm{TL} /$ year. The damage caused by pufferfish to the fish entangled in the fishing gear could not be digitized in the present study as well as in the study of Ünal et al. (2015). Table 5 represents fishing gear, labor, fishing losses/damage of the fishers caused by pufferfish.

Table 5. Comparative total monetary losses by fishing vessel attributed to the silver-cheeked toadfish

\begin{tabular}{|c|c|c|c|c|c|}
\hline \multirow[t]{2}{*}{ Loss items } & \multirow{2}{*}{$\begin{array}{r}\text { Years } \\
2011-2012\end{array}$} & \multirow{2}{*}{ 2013-2014 } & \multicolumn{2}{|c|}{$\begin{array}{l}\text { Annual monetary loss (TRY) } \\
\text { Mean } \pm S D\end{array}$} & \multirow[b]{2}{*}{$\begin{array}{l}\text { Proportion of the } \\
\text { change (\%) }\end{array}$} \\
\hline & & & $\begin{array}{l}\text { Ünal et al., } 2015 \\
2011-2012 \\
\text { Value }\end{array}$ & $\begin{array}{l}2013-2014 \\
\text { Value }\end{array}$ & \\
\hline Gear loss & 204 & 215 & $1,232.3 \pm 1,076.2$ & $2,554.4 \pm 2,759.5$ & 107 \\
\hline Labour loss & 137 & 167 & $67.9 \pm 215.5$ & $64.7 \pm 90.1$ & -5 \\
\hline Catch loss & 204 & 215 & $\mathrm{NE}$ & $\mathrm{NE}$ & $\mathrm{NE}$ \\
\hline
\end{tabular}

It was observed that almost all of the fishers (96\%) had no idea about the first reproduction length and age of pufferfish. $96 \%$ of the fishers stated that they wanted to be informed about pufferfish by an expert which would come to their cooperatives and they wanted to receive information on this issue through a seminar or directly from cooperative authorities.

\section{Possible solutions for the silver-cheeked toadfish} problem

\section{a) Implementation of the bounty system}

$92 \%$ of the fishers answered the question "will paying the bounty for fishing pufferfish be useful in the struggle with this problem?" and stated that paying the bounty would be useful. Only $9 \%$ of the fishers said that they would be able to catch pufferfish in case $1 \mathrm{TL}$ is paid for each of pufferfish species (no 
matter small or big). The remaining $91 \%$ stated that $1 \mathrm{TL}$ was a low price, and they would like to catch pufferfish in a large amount if the average price was $6.5 \mathrm{TL}$ per species. The fishers stated that if such an application started, they would be able to catch at least 50 pufferfish/year per fisher and maximum 5,000 pufferfish/year.

\section{b) Recommendations for policy-makers}

- In order to eliminate the damage caused by pufferfish, only $1 \%$ of the fishers took support from any institution or organisation (cooperative, district offices, local government, fishmonger, etc.).

- The fishers' expectations from official institutions (General Directorate of Fisheries and Aquaculture, universities, and other institutions) are as following:

- The bounty system should be brought, and a satisfactory payment should be made per pufferfish landed.

- Studies on the problems created by pufferfish should be increased.

- Fishing gear support should be provided to fishers.

- Fishers should be informed about pufferfish and problems it creates.

- Fishing of the species should be encouraged.

- Fishing of pufferfish by purse seiners should be allowed in certain periods of the year.

- In order to solve the problem of pufferfish, related institutions should come together and find a solution.

c) Determination of the most appropriate fishing gear against the silver-cheeked toadfish

Another solution to solve the problem of the silver-cheeked toadfish is to develop the most appropriate fishing gear to eliminate it from the ecosystem. In the interviews held with the fishers, only $6 \%$ of them stated that making changes that would prevent the silver-cheeked toadfish from damaging gillnets or longline sets was possible. Upon evaluating the fishers' order of priority, hand-fishing line $(30 \%)$, longline $(26 \%)$, and seine $(20 \%)$ were selected as a fishing gear that catches the silvercheeked toadfish in the largest amount/in the best way. Moreover, they stated that purse seine fishing is the most effective fishing gear in the periods when the silver-cheeked toadfish form dense schools.

It has been stated that the following changes can be made: fishing line with steel wire passing from the main body in longline set (no:0.60-0.70), snood 1-1.2 m in length to connect to the main body after 5-7 fathoms (-fishing line with steel wire passing from inside in the same manner (no:0.40-0.50)), hooks to be attached to snood in the form of straight hook no:10-14 (Pers. comm., T. Özcan).

The number of hooks in the bait set can be increased according to the size and depth. Catching the silver-cheeked toadfish can be performed by attaching sardines, white bait (e.g. sephia), and especially octopus leg to the hooks. This kind of fishing should be performed in the daytime since the silvercheeked toadfish is not very active at night.

In the set without bait, as it is understood from its name, no bait is used. However, it is required to polish leadfish hook after each two fish. This set works by being moved under the water (Pers. comm., E. Altınsoy).

\section{DISCUSSION}

This study draws attention to the dimensions of the socioeconomic impact of the silver-cheeked toadfish on small-scale fishers along the Turkish coasts and reveals the measures that must be taken to reduce this impact. While doing so, the findings for the period of 2013-2014 have been comparatively presented with the findings including the period of 2011-2012 of the single study previously conducted in the same region on this issue (Ünal et al., 2015). Therefore, along with the level (dimension) of the socio-economic impact of the silver-cheeked toadfish, numerical findings about the course and direction of this impact have been revealed. The results of the study are expected to address the situation through feasible policy strategies.

Findings of the study support similar studies (Ünal et al., 2013; Ünal et al., 2015; Irmak ve Altunağaç, 2015; Tuney, 2016) reporting that pufferfish damages passive fishing gears used in small-scale fishing. The previous study (Ünal et al., 2015) confirms that existence of the silver-cheeked toadfish has negatively affected fishing operations and incomes of small-scale fishers in Turkey. In that study (2011-2012) 78\% of fishers claimed that fish caught by their fishing gears damaged by silver-cheeked toadfish; however, this rate increased to $97 \%$ in 2013-2014. The changes on the rates indicate the clear increasing on the affected fishers by the silver-cheeked toadfish.

The present study shows that the economic losses of fishers caused by the silver-cheeked toadfish in the period of 2013-2014 clearly increased when compared to the period of 2011-2012. If the fact that the proportional increase in operating costs is higher than the proportional increase in income in the same period is taken into account (Table 3), it can be argued that fishers are in a much more difficult situation financially when compared to the period of 2011-2012. Fishers complain about not taking any measures in order to cope with this problem and about the lack of attention from official institutions. There has been an inversely related link between decreasing income and the number of days at sea which have decreased by $17 \%$ between $2011-2012$ and $2013-2014$. So even though the fishers continue to suffer from the silver-cheeked toadfish, they try to compensate their losses by going to sea more often. However, this is a vicious circle. The solution can be provided with the implementation of rational and effective measures in the struggle with the silver-cheeked toadfish rather than going to sea more often. 
Moreover, the total loss calculated in this study does not cover all economic losses caused by the related species. As Michailidis (2010) reported, the social and economic effects of the presence of the silver-cheeked toadfish to the fisheries, as well as its impact on the ecosystem are very difficult to assess. For example, according to DFMR unpublished data and reports from the artisanal fishermen, there seems to be an effect of the increasing silver-cheeked toadfish population, at least since 2006, on the cephalopod populations in Cyprus. If this is the case, then many commercial species that feed on these cephalopods are indirectly affected by presence silver-cheeked toadfish, and this in its turn affects the catches and income of artisanal fishermen. According to Kalagirou (2013), the silvercheeked toadfish eat many species belong to the taxa of mollusca, crustacea, and fish and total prey identified to species is 92. Along with the aforementioned damages caused by the species to small-scale fishers along the Turkish coasts, its negative impacts may reach totally different points. For instance, the fact that $53 \%$ of the applicants to the fishing vessel buyback program implemented in Turkey in 2012, 2013, 2014 are small-scale vessels in the range of 10-12 meters shows that there is a tendency to escape from small-scale fishing. On the other hand, $62 \%$ of the fishers sold their vessels back to the program are willing to continue fishing by another vessel while $27 \%$ is planning to buy a new vessel (Ünal et al., 2016). So considering overall, it is a complex issue that should be evaluated with multidimentional approach.

In fact, importance of the economic loss caused by the silver-cheeked toadfish is better understood if we compare the values of the loss in 2011-2012 to the values of the 2013-2014 (Table 5) where dramatic increase is seen. On the other hand, the average fishing income increased more than the results of Ünal et al. (2015), but it is still far below the poverty line $(4,008$ TL per month) for a husehold with four persons (TUKSTAT, 2014 ) in the country. If the annual loss caused by pufferfish is considered together with all this information (mentioned above), it will be better understood in what difficult conditions smallscale fishers are trying to maintain their livelihood. The fishers' average losses caused by pufferfish in 2013-2014 are 2,336 TL in longline and 2,821 TL in gillnets. Upon comparing with the results of the previous monitoring study, the meaning of this is that monetary losses caused by pufferfish have demonstrated a $148 \%$ increase in fishing with longline and a $109 \%$ increase in using gillnet. In other words, damages caused by pufferfish to fishers have increased in both types of fishing gear. Of course, the worst of all is that no measures have been taken in this regard yet.

Silver-cheeked toadfish is considered to be a serious hazard for consumer since it contains a strong marine toxin called tetrodotoxin-TTX, a heat-stable and water-sluble neurotoxin which can be lethal to humans (Nadar et al., 2012; Ünal et al., 2015; Tuney, 2016). However, in this study it was observed unconscionsly consumption of silver-cheeked toadfish by fishers. The rate of the fishers consuming pufferfish was determined to be $29 \%$ in $2011-2012$ (19\% of them got poisoned). In 2013-2014, 38\% of the fishers reported that they consumed pufferfish, and $11 \%$ of those who consumed it stated that they experienced the symptoms of intoxication. An increase in the consumption of pufferfish despite its being poisonous shows that studies on raising the awareness in this regard have not been effective enough.

Therefore, comprehensive awareness studies should be urgently initiated. Further concerns related to this species include the actual attack on humans through biting. For example, a tourist in Antalya-Manavgat was bit in the back, whilst a fisher from Antalya-Gazipaşa suffered problems in one of his fingers due to a toadfish bite.

The fishers suggested (i) the implementation of the sustainable bounty system (ii) the usage of the appropriate fishing gear to remove the silver-cheeked toadfish from the ecosystem, as a solution to the problem of the silver-cheeked toadfish. The bounty system is not a solution suggested in this study (Anon., 2012; Anon., 2016; Ulman, et al., 2014; Ünal et al., 2015; Anon., 2016). In addition to this, it is an application suggested and accepted as a solution by the fishers interviewed within the scope of this study, but an important finding to be considered here is that with the payment of $1 \mathrm{TL}$, only $39 \%$ of fishers reported that they would fish this species in 2011-2012. In 2013-2014, 92\% of the fishers stated that the bounty system would be beneficial. In the case of the payment of $6.5 \mathrm{TL}$ per fish, $67 \%$ of the fishers reported that they would fish this species. That the mentioned rates are high in two studies conducted with the fishers in the same region at a twoyear interval can be interpreted as the fact that the fishers want the solution on their economic problems caused by the silvercheeked toadfish to be found, and that they want to contribute to the solution. However, the payment of $6.5 \mathrm{TL}$ per pufferfish does not seem to be very realistic. For, the TRNC Council of Ministers announced that, within the scope of Article 16 of the decree numbered Ö(K-I) 318-2016 and dated 17.02.2016, it will pay only 2-TL/per fish of support to authorized professional fishers who deliver pufferfish caught (including sports competitions) in 2016 to the Animal Husbandry Department against the damages caused by pufferfish on fishing gears.

In the case of the adoption of the bounty system, it is required to make the fishing of the silver-cheeked toadfish set free in accordance with certain rules and develop a fishing gear suitable for this. In this context, the ranking of fishing gears that can catch the silver-cheeked toadfish most effectively is as follows: hand fishing line (30\%), longline $(26 \%)$ and seine $(20 \%)$. In addition to this, it was reported that the silver-cheeked toadfish is caught most effectively with purse seine in the periods when it forms dense schools. These results can shed light on the relevant decisions that will be taken by fishery managers.

The immediate expectations of the fishers from official institutions (General Directorate of Fisheries and Aquaculture, universities, and other institutions) are as following: (i) implementation of the bounty system and making a satisfactory 
payment per the silver-cheeked toadfish, (ii) increase of the studies on the problems created by the silver-cheeked toadfish, (iii) providing fishing gear support to the fishers suffering a loss, (iv) informing about the silver-cheeked toadfish and problems it creates and encouraging to fish the species. Similarly, Michailidis (2010) suggested to increase fishing pressure on big individuals before they reproduce as a possible solution for the problem. Furthermore, Corsini-Foca et al. (2010) reported that landing prohibition of silver-cheeked toadfish leads to the loss of large biomasses.

\section{CONCLUSION}

The silver-cheeked toadfish is included in the list of the 100 "worst invasives" in the Mediterranean (Streftaris and Zenetos, 2006). This species entered Turkish waters in 2003 (Akyol et al., 2005) and since then it has been a part of the ecosystem. Effects are very versatile and not known very well (except the one in Turkey related to socio-economics). Even though there is such a situation in Turkey, there is no management measures that has been put in practice yet to cope with this problem. Research and management gaps are clear. The first and only study (Ünal et al., 2015) which has been carried out in the Eastern Mediterranean focused on socio-economic impacts of this species and it reflects simply the picture of the 2011. The present study conducted after two years by the same researchers, at the same area by using the same methodology indicates that the negative effects of silver-cheeked toadfish on

\section{REFERENCES}

Anonymous 2012. Balon baliklarının toplatılması. Karar no: 1621/2012 Onerge no: K(II) 1697-2012. [Withdrawl of the Puffer fish species from the fishermen. Motion. No: 1621/2012, Resolution number: K(II) 1697-2012. [in Turkish] Ministry of Agriculture and Natural Resources, Turkish Republic of Northern Cyprus.

Anonymous 2016. Balon baliklarının toplatılması. Karar numarası: (K-I) 3182016, Madde: 16. [Withdrawl of the Puffer fish species from the fishermen. Motion. No: (K-I) 318-2016, Resolution number: 16-2016] [in Turkish] Ministry of Agriculture and Natural Resources, Turkish Republic of Northern Cyprus.

Akyol, O., Ünal, V., Ceyhan T., \& Bilecenoglu, M. (2005). First confirmed record of Lagocephalus sceleratus (Gmelin, 1789) in the Mediterranean Sea. Journal of Fish Biology, 66 (4): 1183-1186 doi: 10.1111/j.0022-1112.2005.00667.x

Baxter, J., Bradley, M., Connor, D., Khan, J., Murray, E., Sanderson, W., Turnbull, C., \& Vincent, M. (2001). Marine Monitoring Handbook. Jon Davies (Eds.), UK Marine SACs project. 405 p. ISBN 1861075243.

Bunce, L., P. Townsley, R. Pomeroy, \& R. Pollnac. (2000). Socioeconomic manual for coral reef management. Global Coral Reef Monitoring Network, Australian Inst. Marine Science, Townsville, Australia, 251 p.

Cai, J., Leung, P., Pan, M., \& Pooley, S. (2005). Economic linkage impacts of Hawaii's longline fishing regulations. Fish. Res. 74: 232-242. doi: 10.1016/j.fishres.2005.02.006

Cochrane, K., De Young, C., Soto, D., \& Bahri, T. (2009). Climate change implications for fisheries and aquaculture: overview of current scientific knowledge. FAO Fisheries and Aquaculture Technical Paper. No. 530, 212p. Rome.

Corsini-Foca, M., Papadopoulou, M.A.P., \& Kalogirou, S. (2010). Is the Lessepsian province in expansion? The Aegean Sea experience. In FAOEastMed Technical Documents 04, Report of the sub-regional technical small scale fisheries along the Turkish coasts of the Mediterranean continue to increase.

The monetary loss in small-scale fishing doubled within two years. It is known that small-scale fishers are trying to survive under the difficult socio-economic conditions. To reveal whether the silver-cheeked toadfish has an impact on this is beyond the purpose of this study; however, it may be one of the issues to be addressed in future studies. Therefore, next step on the silver-cheeked toadfish phenomenon should focus on starting multidimentional monitoring studies (association and interaction with other species and ecosystem, impact on food web, biodiversity, socio-economic impact) and also take urgent decision based on best available scientific data.

\section{ACKNOWLEDGMENTS}

The data of this study has been derived from the UNDP-GEF-SGP project code numbered TUR/SGP/OP5/STAR/BD/13/02, managed by Mediterranean Conservation Society. We would like to thank Mediterranean Conservation Society for their support and also Yalçın Kaya for his assistance during the field works of the study. We are very grateful to Alicia Said for the language editing and constructive suggestions to improve the paper.

meeting on the Lessepsian migration and its impact on Eastern Mediterranean fishery, GCP/INT/041/EC-GRE-ITA/TD-04, $132 p$

Dyer, C.L., \& Poggie, J.J. (2000). The natural resource region and marine policy: a case study from the New England Groundfish fishery. Marine Policy, 24:245-255. doi: 10.1016/S0308-597X(99)00021-4

EASTMED. (2010). Report of the sub-regional technical meeting on the Lessepsian migration and its impact on Eastern Mediterranean fishery. FAO, EastMed Project, Athens. GCP/INT/041/EC-GRE-ITA/TD-04

Fischer, J., Jorgensen, J., Josupeit, H., Kalikoski, D. \& Lucas, C.M. (2015). Fishers' knowledge and the ecosystem approach to fisheries: applications, experiences and lessons in Latin America. FAO Fisheries and Aquaculture Technical Paper No. 591, 278 pp. Rome, FAO.

Freudenburg, W.R. (1986). Social impact assessment. Annu. Rev. Sociol. 12: 451-478. doi: 10.1146/annurev.so.12.080186.002315

Galil, B.S. (2008). Alien species in the Mediterranean Sea - which, when, where, why? Challenges to marine ecosystems. Hydrobiologia, 606: 105116.

Genovesi, P., \& Shine, C. (2004). European strategy on invasive alien species Convention on the Conservation of European Wildlife and Habitats (Bern Convention) Nature and environment, No. 137 Council of Europe Publishing ISBN 92-871-5488-0, 17pp.

Hall, A. M., Pomeroy, C., \& Conway, F. (2009). Figuring out the human dimensions of fisheries: illuminating models. Mar. Coast. Fish.: Dyn. Manag. Ecosyst. Sci. 1(1): 300-314, doi: 10.1577/C09-006.1

IUCN. (2015). The IUCN Monitoring and Evaluation Policy (Version 2.1 / April 2015). Office of the Director General, Switzerland, 12p.

Irmak, E., \& Altunağaç, U. (2015). Fırst record of an invasive lessepsian migrant, lagocephalus sceleratus (actınopterygı: tetraodontiformes: tetraodontidae), in the Sea of Marmara. Acta Ichthyologica et Piscatoria, 45 (4): 433-435. doi: 10.3750/aıp2015.45.4.14 
Kalogirou, S. (2013). Ecological characteristics of the invasive pufferfish Lagocephalus sceleratus (Gmelin, 1789) in Rhodes, Eastern Mediterranean Sea. a case study. Mediterranean Marine Science, 14 (2) 251-260. doi: 10.12681/mms.364

Katsanevakis, S., Deriu, I., D’Amico, F., Nunes, L.A., Sanchez, P.S., Crocetta F., Arianoutsou, M., Bazos, I., Christopoulou, A., Curto, G., Delipetrou, P. Kokkoris, Y., Panov, V.E., Rabitsch, W., Roques, A., Scalera, R., Shirley, S.M.,Tricarico, E., Vannini, A., Zenetos, A., Zervou, S., \& Cardoso, C.A (2015). European Alien Species Information Network (EASIN): supporting European policies and scientific research. Management of Biological Invasions, 6 (2): 147-157. doi: 10.3391/mbi.2015.6.2.0

Michailidis, N. (2010). Study on the lessepsian migrant Lagocephalus sceleratus in Cyprus. In FAO-EastMed Technical Documents 04, Report of the sub-regional technical meeting on the Lessepsian migration and its impact on Eastern Mediterranean fishery, GCP/INT/041/EC-GRE-ITA/TD$04,132 p$.

Nader M., Indary S., \& Boustany L. (2012). FAO EastMed The Puffer Fish Lagocephalus sceleratus (Gmelin, 1789) in the Eastern Mediterranean. GCP/INT/041/EC - GRE -ITA/TD-10.

Miran, B. (2003). Temel İstatistik. [Basic Statistics.] Ege University Publishing House, İzmir, Turkey. [In Turkish.]

Nehring, S., Reise, K., Dankers, N., \& Kristensen, P. S. (2009). Alien species Thematic Report No. 7. In: Marencic, H. \& Vlas, J. (Eds.), Quality Status Report 2009. WaddenSea Ecosystem No. 25. Common Wadden Sea Secretariat, Trilateral Monitoring and Assessment Group, Wilhelmshaven, Germany. 28p.

Newbold P., Carlson W.L., \& Thorne B.M. (2013). Statistics for business and economics. Global edition. Pearson Education Limited.

Otero, M., Cebrian, E., Francour, P., Galil, B., \& Savini, D. (2013). Monitoring marine invasive species in Mediterranean Marine Protected Areas (MPAs): A strategy and practical guide for managers. Malaga, Spain: IUCN. 136 p. ISBN: 979-2-8317-1615-2.

Pollnac, R.B., Abbott-Jamieson, S., Smith, C., Miller, M.L., Clay, P.M., \& Oles, B. (2006). Toward a model for fisheries social impact assessment. Marine Fisheries Review,68: 1-4, pp. 1-18.

Pomeroy, R.S., Parks, J.E., \& Watson, I.M. (2004). How is your MPA ding? A Guidebook of Natural and Social Indicators for Evaluating Marine Protected Area Management Effectiveness, IUCN, Gland, Switzerland and Cambridge, 234p. UK. ISBN:2-8317-0735-8

Richmond, L., Kotowicz, D., \& Hospital, J. (2015). Monitoring socioeconomic impacts of Hawaii's 2010 bigeye tuna closure: Complexities of local management in a global fishery. Ocean \& Coastal Management, 106: 8796.

Shine, C., Kettunen, M., Genovesi, P., Gollasch, S., Pagad, S., \& Starfinger, U. (2008). Technical support to EU strategy on invasive alien species (IAS). Policy options to minimise the negative impacts of invasive alien species on biodiversity in Europe and the EU, Institute for European Environmental Policy, 231p. Service contract No 070307/2007/483544/MAR/B2

SUBiS, 2013. Balikcilik Bilgi Sistemi (Fisheries Information System) (in Turkish) Retrieved from http://subis.tarim.gov.tr/ (10.12.2014)

Streftaris, N., \& Zenetos, A, (2006). Alien marine species in the Mediterranean -the 100 worst invasives and their impact. Mediterranean Marine Science, 7:87-118
Tuney, I. (2016). Molecular identification of puffer fish Lagocephalus sceleratus (Gmelin, 1789) and Lagocephalus spadiceus (Richardson, 1845) from Eastern Mediterranean, Turkey. Fresenius Environmental Bulletin, 25 (5):1428-1436.

Tuler, S.P., Webler, T., \& Polsky, C. (2013). A rapid impact and vulnerability assessment approach for commercial fisheries management. Ocean \& Coastal Management, 71: 131-140 doi:10.1016/j.ocecoaman.2012.09.013

TUKSTAT. (2014). Labour force statistic 2014. Retrieved from https://biruni.tuik.gov.tr/medas/?kn=72\&locale=tr (17.03.2016).

UNEP-MAP-RAC/SPA. (2005). Action Plan concerning species introductions and invasive species in the Mediterranean Sea . Ed. RAC/SPA, Tunis. 30 pp.

UNEP-MAP-RAC/SPA. (2011). Non-native species in the Mediterranean: What, when, how and why? Ed: RAC/SPA, Tunis. 28 pp.

Ulman A., Çiçek B. A., Salihoglu I., Petrou A., Patsalidou M., Pauly D., \& Zeller D. (2014). Unifying the catch data of a divided island: Cyprus's marine fisheries catches, 1950-2010. Environment, Development and Sustainability, 16 (4): 801-821.

Ünal, V., Göncüoğlu, H., Durgun, D., Tosunoğlu, Z., \& Deval, C. (2013). Assessing economic impacts of pufferfish along the Turkish coast (Eastern Mediterranean. SAC meetings of the Sub-Committees, (SCSI, SCSA, SCESS, SCMEE), 13th Session of the Sub-Committee on Economic and Social Sciences (SCESS), 18 - 20 February 2013, FAO, HQ, Rome, Italy.

Ünal, V., Göncüoğlu, H., Yercan, M., \& Tosunoğlu, Z. (2014). Profiling marine fishery cooperatives in Turkey. Ege University Scientific Research Projects, 2010/SÜF/010. 207p.

Ünal, V., Göncüoğlu, H., Durgun, D., Tosunoğlu, Z., Deval, C., \& Turan, C. (2015). Silver-Cheeked Toadfish, Lagocephalus sceleratus (Actinopterygii: Tetraodontiformes: Tetraodontidae), Causes A Substantial Economic Losses In The Turkish Mediterranean Coast: A Call For Decision Makers. Acta Ichthyologica et Piscatoria, 45 (3): 231-237. doi: 10.3750/AIP2015.45.3.02

Ünal, V., Ekmekci, B., Göktay, S., \& Göncüoğlu, H. (2016). Analyses of fisheries buy-back programs in Turkey: preliminary results. National Conference of Marine Science, ODTÜ, 31 May-3 June 2016, Ankara (published only abstract).

Vanderpool, C.K. (1987). Social impact assessment and fisheries. Transactions of the American Fisheries Society, 116 (3): 479-485. doi: 10.1577/1548-8659(1987)116<479:SIAAF>2.0.CO;2

Wongbusarakum, S., \& Loper, C. (2011). Indicators to assess community-level social vulnerability to climate change: An addendum to SocMon and SEMPasifika regional socioeconomic monitoring guidelines, The Coral Reef Initiatives for the Pacific (CRISP) and IUCN. 41p.

Zenetos, A., Gofas, S., Verlaque, M., Cinar, M.E., Garcia Raso, J.E., Bianchi, C.N., Morri, C., Azzurro, E., Bilecenoğlu, M., Froglia, C., Siokou, I., Violanti, D., Sfriso, A., San Martin, G., Giangrande, A., Katağan, T., Ballesteros, E., Ramos-Espla, A.A., Mastrototaro, F., Ocana, O., Zingone, A., Gambi, M.C., \& Streftaris, N. (2010). Alien species in the Mediterranean Sea by 2010. A contribution to the application of European Union's Marine Strategy Framework Directive (MSFD). Part I. Spatial distribution. Medit. Mar. Sci., 11(2): 381-493. doi: $10.12681 / \mathrm{mms} .8$ 